\title{
Amylase in Obstetrics and Gynecology: Review
}

\author{
Obstetrik ve Jinekolojide Amilaz
}

\section{Ayla ESER, ${ }^{a}$ \\ İkbal KAYGUSUZ, \\ Nermin KÖȘÜŞ, ${ }^{a}$ \\ Aydın KÖȘÜŞ, \\ İlknur INEGÖL GÜMÜŞa}

aDepartment of Gynecology and Obstetrics Turgut Özal University Faculty of Medicine, Ankara

Geliş Tarihi/Received: 23.04 .2014

Kabul Tarihi/Accepted: 03.09.2014

Yazışma Adresi/Correspondence:

Ayla ESER

Turgut Özal University Faculty of Medicine, Department of Gynecology and Obstetrics,

Ankara,

TÜRKIYE/TURKEY

aylaacar76@yahoo.com.tr doi: 10.5336/gynobstet.2014-40276

Copyright $@ 2016$ by Türkiye Klinikleri
ABSTRACT Amylase is one of the main enzymes of the digestive system. It is principally produced by the pancreas and the salivary glands. In the digestive system, its main function is digestion of carbohydrates to break down starch into maltose. Now, amylase has been widely recognized as a very important tool in the medical field. Too little or too much of amylase in the blood is an indication of a variety of problems, particularly with the pancreas. Now, salivary/serum/uterine amylase tests are being used extensively in the obstetrics and gynecology. These simple but wonderful tests have been found to be very effective and reliable, in the identification of certain gynecological diseases and disorders. For instance, the high level of amylase could be an early sign of ovarian cancer, ruptured ectopic pregnancy when the low levels of blood amylase can be a predictor of preeclampsia. Human uterine amylase may be related to infertility. The other related conditions may be hyperamylasemia in response to ritodrine or ephedrine and macroamylasemia in pregnant patients, etc. At the same time, amylase has now been identified as a stress marker and is consequently being used for identification of several stress-related complications that greatly affect women. Especially salivary amylase used to as a stress biomarker in pregnant patients.

Key Words: Amylases; obstetrics; gynecology

ÖZET Amilaz sindirim sisteminin temel enzimlerinden birisidir. Başlıca pankreas ve tükrük bezleri tarafından üretilir. Sindirim sistemindeki temel fonksiyonu karbonhidrat sindirim olup, nişastayı maltoza parçalamaktır. Güncel tıp alanında çok önemli bir araç olarak kabul edilmektedir. Kandaki çok az ya da çok fazla miktarda amilaz, özellikle pankreasla ilgili olan çeşitli sorunların göstergesidir. Günümüzde tükrük-serum-uterin amilaz testleri obstetrik ve jinekolojide yaygın olarak kullanılmakadır. Bu basit ama muhteşem testlerin bazı jinekolojik hastalık ve bozuklukların tanımlanmasında çok etkili ve güvenilir olduğu görülmüştür. Örneğin yüksek amilaz seviyesi over kanserinin, rüptüre olmuş dış gebeliğin erken bulgusu olabilirken düşük amilaz seviyeleri preeklampsinin belirteci olabilir. Uterin amilaz infertilite ile ilişkili olabilir. Diğer ilişkili durumlar gebe hastalarda ritodrin ve efedrine cevap olarak hiperamilazemi ve makroamilazemidir. Aynı zamanda amilaz bir stres belirteci olarak tanımlanmıştır ve dolayısıyla büyük ölçüde kadınları etkileyen birçok stresle ilgili komplikasyonun tanımlanması için kullanılmaktadır. Özellikle tükrük amilazı gebe hastalarda bir stres belirteci olarak kullanılmaktadır.

Anahtar Kelimeler: Amilazlar; doğumbilim; jinekoloji

Turkiye Klinikleri J Gynecol Obst 2016;26(2):109-13

\section{SALIVARY AMYLASE AS A STRESS BIOMARKER IN PREGNANT PATIENTS}

alivary biomarkers, such as $\alpha$-amylase are becoming more and more popular in stress research. The increasing popularity is hugely attributed to their ease of production in the human body as well as ease of collection, which is neither invasive nor limited by geographical distance or lack of infra- 
structures. ${ }^{1}$ Thus, it's not surprising that salivary biomarkers have gained popularity in stress research as it has proven superior to testing biomarkers in blood.

The salivary $\alpha$-amylase is produced in the acinar cells and then stored in granules, from where it's eventually released into the saliva in response to neuronal stimuli. ${ }^{2}$ The release of salivary $\alpha$-amylase frequently occurs, when the Sympathetic Nervous System is stimulated. In other words, the process is governed by the Sympathetic Nervous, which is usually stimulated under stressful situations. This clearly explains why salivary $\alpha$-amylase is a very nice biomarker for stress. ${ }^{3}$

Several studies have shown that salivary $\alpha$ amylase is highly sensitive to stress-related changes. Such changes include psychological stress (for example, pregnant women that are about to undergo a cesarean section) and physical stress (for example, individuals doing physical work). ${ }^{2}$

During pregnancy, chronic stress has been directly linked to worsened maternal, obstetric or fetal outcomes and poor pain relief during labor. Similarly, pregnant patients may experience hypotension as a result of acute stress immediately before spinal anesthesia for caesarean section. ${ }^{4}$ During these cases, the level of salivary $\alpha$-amylase is highly elevated. This is confirmed by a study conducted by Guglielminotti et al. Guglielminotti et al in an attempt to find out if salivary $\alpha$-amylase increases in pregnant patients submitted to the stress of the transfer to the operating room and the significant of such increase, measured the systolic blood pressure, heart rate and immediate anxiety of 15 pregnant women about to undergo planned caesarean section under spinal anesthesia. ${ }^{5}$ The measurements were carried out in the morning of the surgery and also in the operating room. Reference change value (RCV) was calculated in 18 healthy volunteers. ${ }^{5} \mathrm{At}$ the end of the experiment, it was found that the median 22\% increase in Salivary alpha-amylase (SAA) activity ( $\mathrm{p}=0.0015)$ and a median $17 \%$ increase in systolic blood pressure $(\mathrm{p}=0.0006)$ were recorded between the two events among the pregnant patients, i.e. between the morning of the surgery and the time in the operating room. There was no change of heart rate or immediate anxiety. The
RCV among the volunteers was $\pm 76 \%$ while 13 out of the 15 pregnant patients had an SAA increase greater than the RCV. The result clearly shows a statistical and analytical increase in pregnant patients under stressful conditions.

The result obtained by Guglielminotti and his team is quite similar to that of Orbach-Zinger and his team. ${ }^{6}$ Orbach-Zinger et al who in their study to determine Influence of preoperative anxiety on hypotension after spinal anaesthesia in women undergoing Cesarean delivery found that the preoperative anxiety assessed by verbal analogue scale (VAS) had a significant effect on the hypotension after spinal anaesthesia. ${ }^{6}$

\section{ELEVATED SERUM AMYLASE LEVEL ASSOCIATED WITH RUPTURED ECTOPIC PREGNANCY}

Ectopic Pregnancy is a serious disease that results, when the fetus develops outside the uterus, typically in the fallopian tube. This defect is capable of causing massive hemorrhage, infertility or even death. So, it's very important for such dangerous disease to be promptly identified and treated before it becomes fatal.

Serum amylase and lipase measurements are known biochemical markers of pancreatic inflammation. So, they offer convenient and reliable ways, through which acute pancreatitis can be identified. Mitura and Romanczuk offers one of the very first cases of ruptured ectopic pregnancy accompanied by markedly elevated amylase and lipase levels mimicking acute pancreatitis ever reported. ${ }^{7}$ The study confirmed that ruptured ectopic pregnancy that are misdiagnosed in course of elevated activities of pancreatic enzymes may lead to delayed diagnosis of haemorrhage to peritoneum, which can give rise to hemodynamic instability. ${ }^{7}$

\section{HUMAN UTERINE AMYLASE IN RELATION TO INFERTILITY}

It's now known that stress hormone can obstruct a successful implantation of a fertilized egg. Previous studies have confirmed uterine $\alpha$-amylase, to be the key indicator of this stress. It specifically acts by 
slowing down blood flow, which in turn slows the passage of the fertilized egg to the uterus. Several researches also showed that, women with higher levels of $\alpha$-amylase were less likely to conceive in their fertile window. In terms of physiological actions, infertile women experienced lower amylase activity in their uterine fluid, during the menstrual cycle. This low enzyme activity may impair sperm capacitation and adversely affect fertility. This is not surprising, as the uterine amylase activity is under the influence of the ovarian hormones, which facilitate the ability of the sperm to fertilize the female egg. Acid phosphatase is also capable of hindering amylase activity, which may in turn lead to infertility. ${ }^{8}$ Similarly, Kumar et al. in an investigation of amylase activity in cervical mucus and serum during estrus in normal and repeat breeder cattle, found that cervical mucus amylase could also be a significant facilitator of sperm transport and capacitation process in mammalian females. ${ }^{9}$

\section{HYPERAMYLASEMIA IN RESPONSE TO RITODRINE}

Hyperamylasemia is a health disorder that is characterized by excess amylase in the blood. It is one of the indications of pancreatitis. The level of lipase, in the human blood, can also be used to diagnose pancreatitis. This is possible because; both amylase and lipase (from gastric secretions) are released at the same time during digestion.

When the pancreas is inflamed, increased blood levels of amylase and lipase will result. The normal level for amylase is $0-137 \mathrm{U} / \mathrm{L} .{ }^{10}$ Normal values may vary from laboratory to laboratory. Even though the serum amylase is elevated in at least $75 \%$ of pancreatitis cases, it's very possible for the amylase level to remain normal, in the remaining $25 \%$ even in the course of a massive pancreatic necrosis. ${ }^{10}$ The major limitation of using serum amylase measurement in diagnosing pancreatitis is the lack of specificity.

The main causes of hyperamylasemia are acute or chronic pancreatitis, pseudocysts, pancreatic ascites, pancreatic trauma, choledocholithiasis, salivary diseases, intestinal disease, female reproductive tract disease etc.
There has been conflicting reports on how hyperamylasemia respond to ritodrine, a drug used for tocolytic treatment of preterm labor. Whereas some researchers believe the drug is capable of inducing hyperamylasemia in pregnant women, others research revealed that the level of amylase in the blood is not affected by its administration. Up till now, the incidence of these beta-agonistinduced hyperamylasemia and how they interact with serum amylase activity are not yet known.

In a study aimed at assessing the exact response of hyperamylasemia to ritodrine, Takahashi et al., (1997) measured the serum amylase level of selected pregnant women. The measurement was conducted, 12 to 24 hours after administrating ritodrine alone $(n=140)$, ephedrine alone $(n=160)$, ephedrine and ritodrine simultaneously $(\mathrm{n}=34)$, and ephedrine after prolonged ( $>$ or $=7$ days) use of ritodrine ( $\mathrm{n}=101) .{ }^{11}$ The serum level of volunteers, who weren't treated with any of the drugs, was also measured. The result obtained, shows significantly high level of hyperamylasemia (amylase $>215$ IU/L) in the women that were treated with ritodrine alone (60/140, 43\%); ephedrine alone (54/160, $34 \%)$, or ephedrine plus ritodrine $(24 / 34,71 \%)$ compared with untreated pregnant women (21/426, 4.9\%). ${ }^{11}$ Furthers tests revealed that the hyperamylasemia in the affected women was mainly caused by the hypersecretion of salivarytype amylase. ${ }^{11}$ Thus, Takahashi et al. was of the opinion that ephedrine and ritodrine are capable of inducing hyperamylasemia in about one-third of pregnant women. However, the team believes that the incidence of desensitization to beta-agonists may occur after prolonged use of ritodrine. ${ }^{11}$

Takahashi's findings have been greatly contradicted by recent research. For instance, Nakajima and Masaoka, in the evaluation of creatine kinase, lactate dehydrogenase, and amylase concentrations in umbilical blood of preterm infants after long-term tocolytic, found that level of amylase remain virtually unchanged. ${ }^{12}$ The study conducted by Nakajima and Masaoka involves 215 preterm infants that were born to women, who are treated with and without ritodrine hydrochloride. The blood levels of creatine kinase, 
lactate dehydrogenase and amylase in the umbilical blood were determined at delivery. The result obtained shows no significant difference in LDH and amylase levels in the sample populations. ${ }^{12}$ The level of the two enzymes did not change with gestational change nor birth weight. ${ }^{12}$ On the other hand, a significant increase in the creatine kinase was recorded. Thus, Nakajima and Masaoka concluded that long-term ritodrine treatment does not lead to hyperamylasemia. Rather, it increases the umbilical blood level of creatine kinase. These changes are physiological and not pathological.

The results obtained from other studies show that the amylase levels remain hugely unchanged, during ritodrine treatment. ${ }^{13,14}$ However, there is still need to conduct more researches aimed at ascertaining the relationship between ritodrine hydrochloride and escape enzymes in the umbilical blood of preterm infants.

\section{MACROAMYLASEMIA}

Macroamylase is a bimolecular complex that is generated when amylase is attached immunoglobulins. The complex is so large that it can only be filtered slowly from the blood by the kidneys. ${ }^{15}$ Generally, macroamylasemia is not specifically caused by any diseases. However, its occurrence has been associated with: Celiac disease, Lymphoma, HIV infection, monoclonal gammopathy, Rheumatoid arthritis and Ulcerative colitis.

Strangely, this disorder has no symptoms. ${ }^{16} \mathrm{It}$ 's primarily identified by the presence of too much amylase in the blood. Unfortunately, this characteristic is synonymous to that of acute pancreatitis, which is also characterized by high levels of amylase in the blood. ${ }^{15}$ However, macroamylasemia usually cause hyperamylasemia with low or normal amylasuria. In every situation, it's very important to identify the real cause of the high level of amylase in the blood, as any misdiagnosis of macroamylase, can lead to costly analyses for ruling out pancreatic disease and unnecessary prescriptions such as fasting and intravenous replacement therapies. ${ }^{16}$
Macroamylasemia can be differentiated from acute pancreatitis through analysis of the urine level of amylase. Generally, the urine levels of amylase are low in people with macroamylasemia but high in patients with acute pancreatitis. So, this discrepancy is usually employed to determine the exact cause of high level of amylase in the blood.

In a specific study in order to fully understand macroamylasemia in pregnant women, Barałkiewicz and Juszczyk found out the essentiality of evaluating urinary and serum amylase isoenzymes. ${ }^{17}$ The essence is to differentiate hyperamylasemia, from macroamylasemia. The study, conducted by the two scientists involved a 31-year-old G2P1, who was complaining of recurring right-sided abdominal pain. The lady also had increased level of serum amylase and had previously been treated for acute cholecystitis (through laparoscopic cholecystectomy) and gallstone pancreatitis. ${ }^{18}$

Blechman and Headley concluded that, in the absence of characteristic findings suggestive of acute cholecystitis or gallstone pancreatitis in pregnant women, medical experts should resort to an analysis of both urinary and serum amylase isoenzymes. ${ }^{18}$ Thus, the most reliable way to know the exact cause of an elevated level of amylase in the human fluid system is by differential diagnosis. ${ }^{17}$ In other words, the possibility of macroamylasemia should always be taken into consideration during the diagnostics of patients, with high serum levels. This becomes even more necessary when the amylase activity in urine is low or normal. It's the surest way to avoid long and tiresome diagnosis, which at times may become invasive.

\section{CONCLUSION}

Even though amylase is an enzyme, whose essential function is to hydrolysis complex starch molecules, its diagnostic applicability cannot be underestimated. This is further boosted by the availability of the enzymes in the human body at any point in time. So, testing the serum amylase 
level remains one of the most convenient ways of testing such medical disorders like acute or chronic pancreatitis, cholecystitis, macroamylasemia, gastroenteritis, perforated ulcer, tubal pregnancy, intestinal blockages, salivary gland infections, preeclampsia, damaged pancreas, kidney disease.
So far, the applicability of amylase in testing certain gynecological diseases and disorders has also been extensively researched and implemented. For example, amylase testing has enabled medical experts to have a better understanding of some medical problems that affect women. However, more research still need to be conducted.

\section{REFERENCES}

1. Yi C, Moochhal S. Mini-review article-current opinion on salivary biomarkers as a measurement for stress and fatigue. The Open Biomarkers Journal 2013;6(1):9-14.

2. Nater UM, Rohleder N. Salivary alpha-amylase as a non-invasive biomarker for the sympathetic nervous system: current state of research. Psychoneuroendocrinology 2009;34(4):486-96.

3. Silverman MN, Heim CM, Nater UM, Marques $\mathrm{AH}$, Sternberg EM. Neuroendocrine and immune contributors to fatigue. PM $R$ 2010;2(5):338-46.

4. Stefaniak A, Kaczmarek U. Salivary a-amylase and cortisol as stress Biomarkers. Dent Med Probl 2013;50(3):271-4.

5. Guglielminotti J, Dehoux M, Mentré F, Bedairia E, Montravers P, Desmonts JM, et al. Assessment of salivary amylase as a stress biomarker in pregnant patients. Int J Obstet Anesth 2012;21(1):35-9.

6. Orbach-Zinger S, Ginosar Y, Elliston J, Fadon C, Abu-Lil M, Raz A, et al. Influence of preoperative anxiety on hypotension after spinal anaesthesia in women undergoing Caesarean delivery. Br J Anaesth 2012;109(6):943-9.

7. Mitura K, Romanczuk M. Ruptured ectopic pregnancy mimicking acute pancreatitis. Ginekol Pol 2009;80(5):383-5.

8. Singh VN. Human uterine amylase in relation to infertility. Horm Metab Res 1995;27(1):35-6.

9. Kumar A, Mehrotra S, Dangi SS, Singh G, Singh M, Mahla AS. Amylase activity in cervical mucus and serum during estrus in normal and repeat breeder cattle. Vet World 2012;5(8):486-8.

10. Frulloni L, Patrizi F, Bernardoni L, Cavallini G. Pancreatic hyperenzymemia: clinical significance and diagnostic approach. JOP 2005;6(6):536-51.

11. Takahashi T, Minakami H, Tamada T, Sato I. Hyperamylasemia in response to ritodrine or ephedrine administered to pregnant women. J Am Coll Surg 1997;184(1):31-6.

12. Nakajima $Y$, Masaoka N. Evaluation of creatine kinase, lactate dehydrogenase, and amylase concentrations in umbilical blood of preterm infants after long-term tocolysis. Ob- stet Gynecol Int 2014;2014:278379.

13. Matsuda $Y$, Nagayoshi $Y$, Kirihara N. Rhabdomyolysis during prolonged intravenous tocolytic therapy. J Perinat Med 2002;30(6):514-6.

14. Nakajima Y, Masaoka N, Tsuduki Y, Honda N, Sakai M. Rhabdomyolysis caused by tocolytic therapy with oral ritodrine hydrochloride in a pregnant woman with placenta previa. J Obstet Gynaecol Res 2011;37(6):629-32.

15. Cho SY, Lee A, Lee HJ, Suh JT. Overlapping presence of macroamylasemia and hyperamylasemia in acute pancreatitis. Korean $\mathrm{J}$ Lab Med 2011;31(2):98-100.

16. Ko JH, Lee DH. Macroamylasemia in a 4year-old girl with abdominal pain. Korean $\mathrm{J}$ Pediatr 2009;52(11):1283-5.

17. Barałkiewicz G, Jacek Juszczy K. Macroamylasemia in an HIV-infected patient-case report. HIV AIDS Rev 2005;4(4):21-3.

18. Headley AJ, Blechman AN. Diagnosis of macroamylasemia in a pregnant patient. J Natl Med Assoc 2008;100(11):1359-61. 